\title{
Herpes simplex encephalitis: unusual imaging appearances
}

\author{
Michael Bonnici-Mallia, ${ }^{1,2}$ Avinash Kumar Kanodia, ${ }^{2}$ Nikolas Rae, ${ }^{1}$ Charis Marwick ${ }^{1}$
}

\begin{abstract}
${ }^{1}$ Ninewells Hospital, Dundee UK

${ }^{2}$ Department of Radiology, Ninewells Hospital, Dundee, UK
\end{abstract}

Correspondence to Dr Avinash Kumar Kanodia, avinash.kanodia@nhs.net

Accepted 23 March 2016

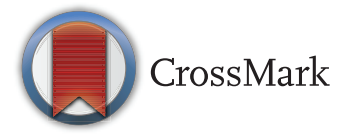

To cite: Bonnici-Mallia $\mathrm{M}$, Kanodia AK, Rae $\mathrm{N}$, et al. $B M J$ Case Rep Published online: [please include Day Month Year] doi:10.1136/ bcr-2016-214993

\section{DESCRIPTION}

Herpes simplex virus (HSV) is the most common non-epidemic and sporadic cause of viral meningoencephalitis with an incidence of approximately 13 cases per million. ${ }^{1}$ Ninety five per cent of fatal adult cases are a result of type 1 HSV (HSV-1) and typically follow latent viral reactivation in the trigeminal ganglion in immunocompetent patients. ${ }^{1}$ MRI is regarded as being the most sensitive radiological investigation, with changes usually visible within 2-3 days of onset of symptoms. ${ }^{1}$ Traditionally on MRI, Herpes simplex encephalitis (HSE) exhibits bilateral asymmetrical involvement of the limbic system, including the medial temporal lobes, insular cortices and inferolateral frontal lobes and cingulate gyri. ${ }^{1}$ Sparing of the basal ganglia is a key feature, which also helps in differentiating from middle cerebral artery infarction on diffusionweighted imaging (DWI). Atypical patterns, if seen, usually affect the younger population with involvement of the cerebral hemispheres and rarely, the midbrain and pons. ${ }^{1}$

We present serial brain imaging of a 52-year-old woman who presented to the acute medical unit with a week's history of lethargy, intermittent headaches and an episode of syncope prior to admission. Over the course of the subsequent $24 \mathrm{~h}$, she developed acute confusion and became hypotensive, hypothermic and bradycardic. CT of the brain was not of any diagnostic value. MRI, however, demonstrated grossly abnormal signal change in the hypothalamic region at the floor of the third ventricle and optic chasm and optic tracts on both sides, with partial involvement of the inferior aspect of the left putamen (figure 1A-D). DWI showed a lesser degree of symmetrical restricted diffusion involving the paramedian structures (figure $1 \mathrm{E}, \mathrm{F}$ ). There was no significant enhancement with intravenous contrast (figure $1 \mathrm{G}, \mathrm{H}$ ). The imaging findings were considered unusual and atypical for usually seen acute neurological conditions, although the possibility of Wernicke encephalopathy was raised.

Lumbar puncture for cerebrospinal fluid (CSF) examination revealed $94 \times 106 / \mathrm{L}$ white cell count (100\% lymphocytes) with elevated CSF protein $(3042 \mathrm{mg} / \mathrm{L})$ and normal CSF glucose $(4.2 \mathrm{mmol} / \mathrm{L})$. Viral PCR on CSF was positive for HSV-1. The MRI scan was reviewed and on literature review, no similar example of HSE was found with similar MRI findings; a possibility of false-positive PCR was also raised, however, sensitivity and specificity of PCR testing for HSV is accepted to exceed 95\%. ${ }^{2}$ Surprisingly, several clinical manifestations of HSE, such as cold sores, were also not present. However, there was no history of alcoholism or gastrointestinal (GI) surgery to have predisposed the patient to Wernicke's encephalopathy.

Patient was treated with antiviral therapy, although due to unusual MRI findings, intravenous thiamine was also given. Patient's hypothermia improved over the next few days and the patient

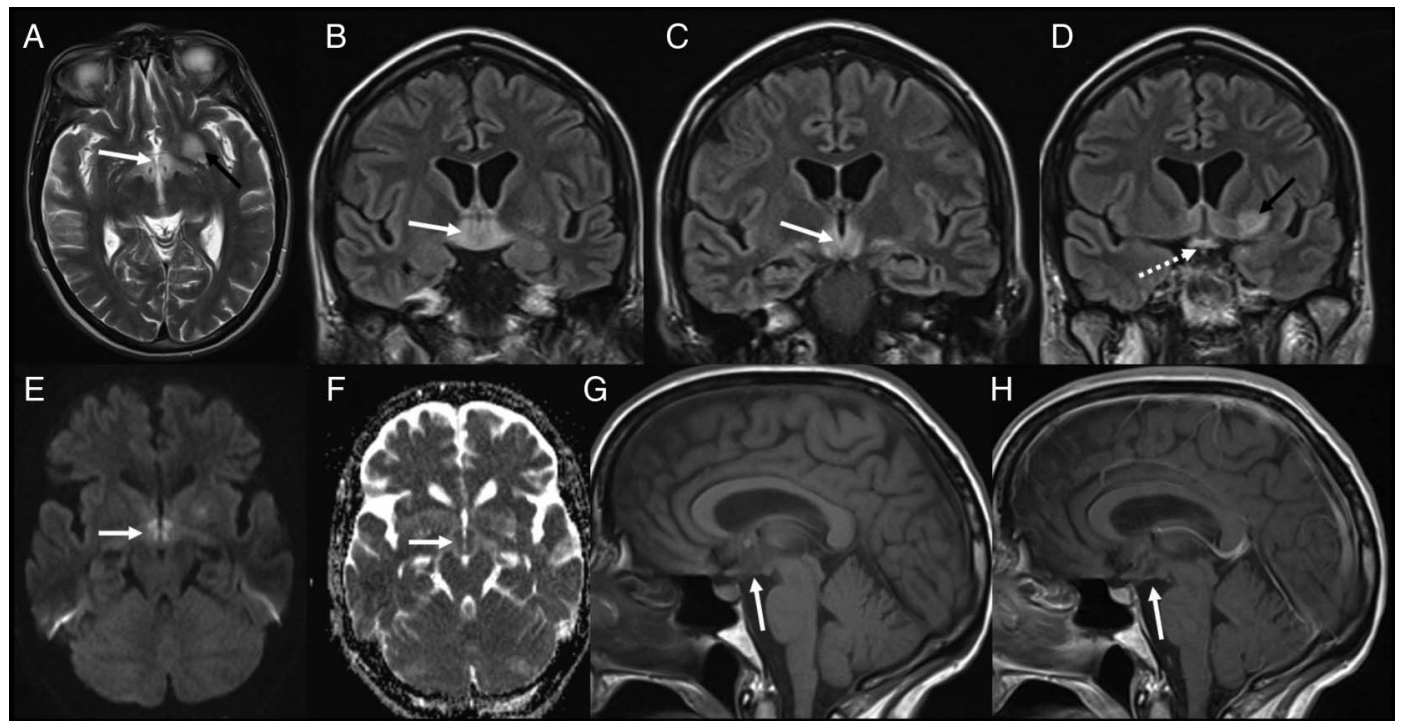

Figure 1 Initial MRI findings. T2 axial (A), fluid-attenuated inversion recovery coronal (B-D) showing hypothalamic and floor of third ventricle involvement (white arrows), putamen involvement (black arrows), optic chiasm involvement (white broken arrow). Diffusion-weighted imaging and apparent diffusion coefficient (C and D) showing smaller areas of restricted diffusion (white arrows). T1 sagittal precontrast (G) and postcontrast $(\mathrm{H})$ showing no enhancement. 
Figure 2 Follow-up MRI at 4 weeks. Fluid-attenuated inversion recovery coronal (A and B) and T2 axial (C) showing improvement in hypothalamic signal (white arrow) and putemen (black arrow). Diffusion-weighted imaging (D) showing reduced signal abnormality (white arrow).

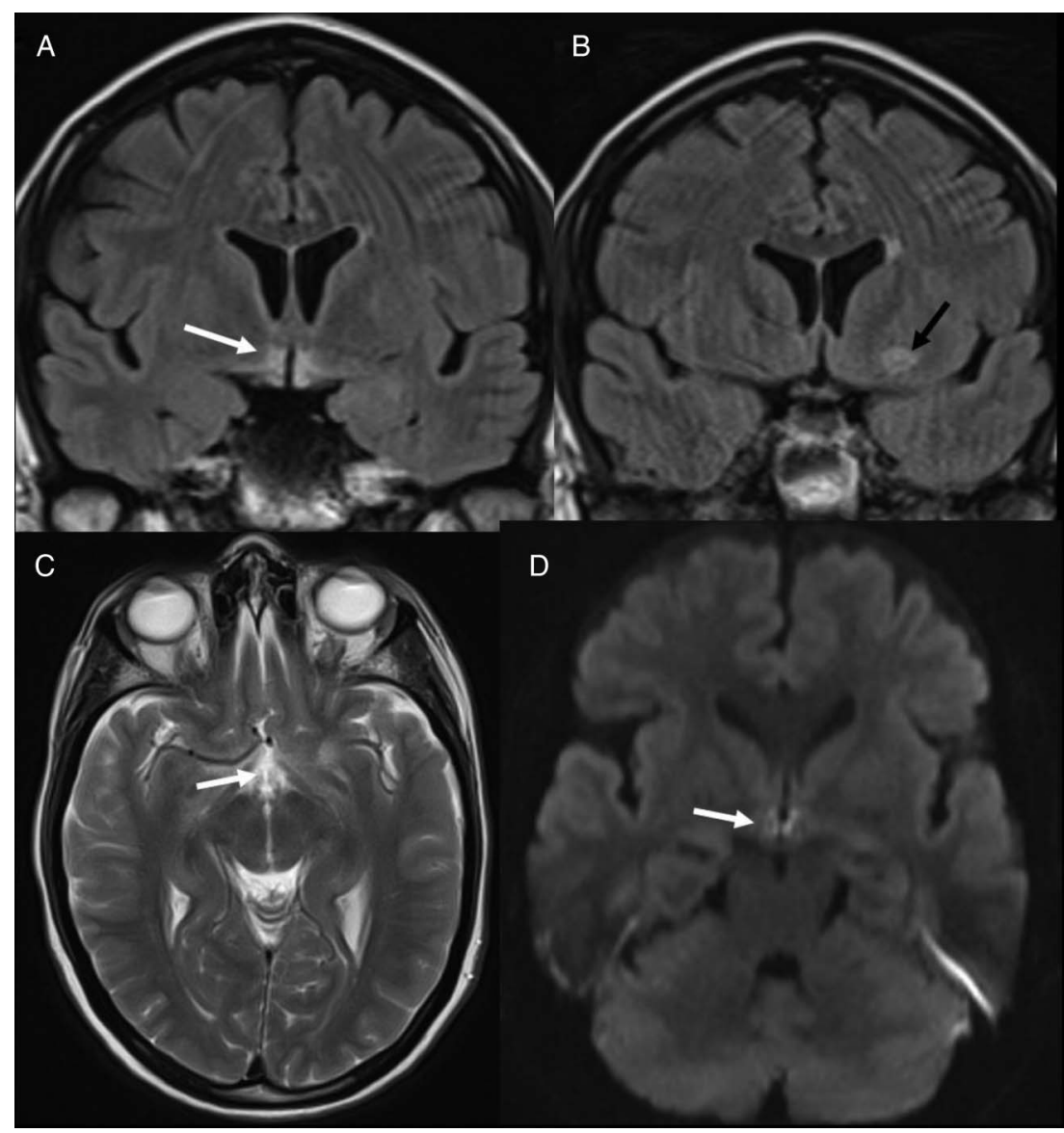

Figure 3 Follow-up MRI at 8 weeks. Fluid-attenuated inversion recovery coronal (A and B) and T2 axial (C) showing further evolution of hypothalamic signal with subtle cavitation (white arrow) and putemen (black arrow). Diffusion-weighted imaging (D) showing resolution of signal abnormality (white arrow).

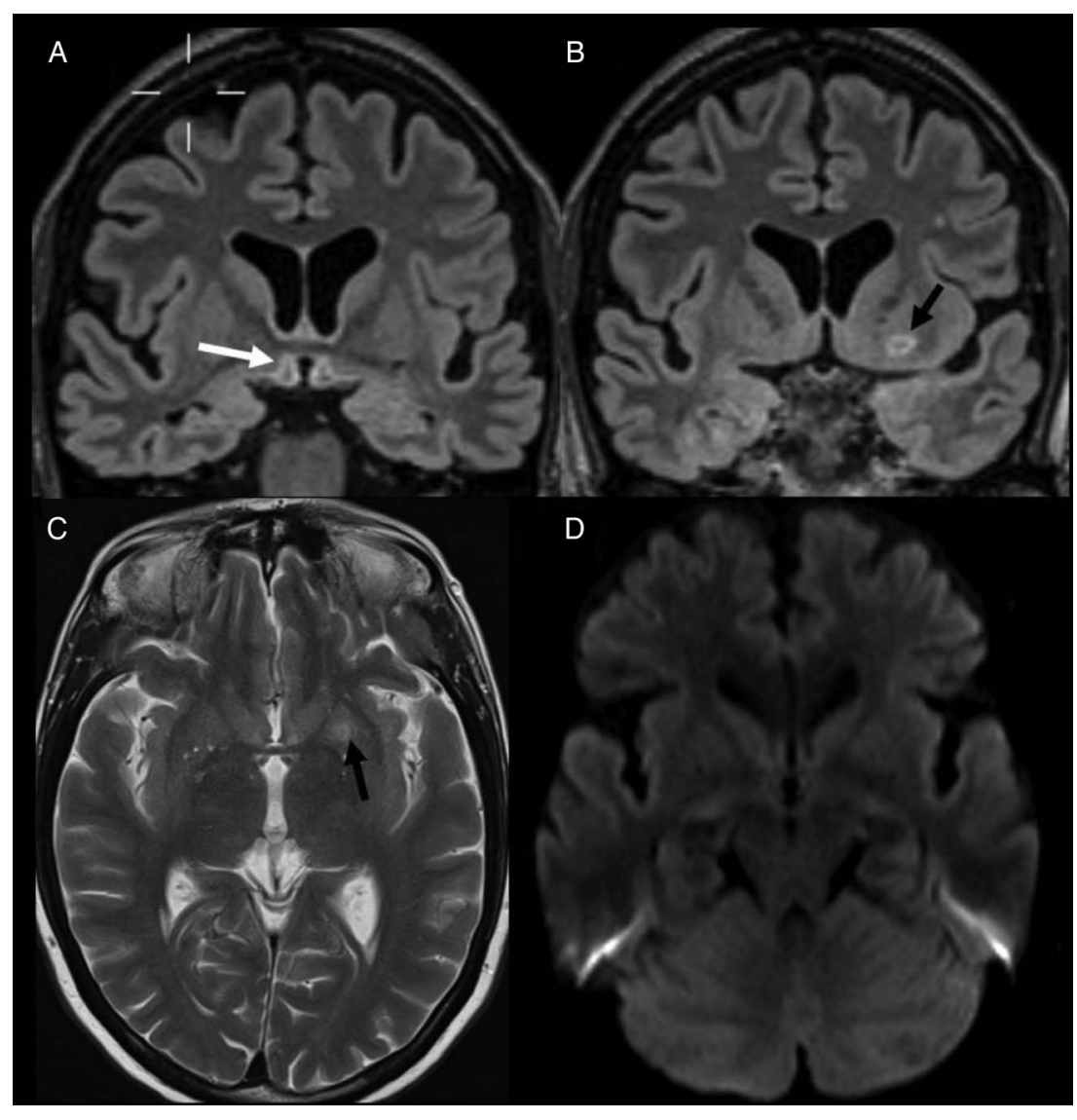


subsequently developed fever. Clinical improvement followed over the course of 2 weeks. Two follow-up MRIs were performed over the next 8 weeks (figures 2 and 3), that revealed an overall improvement in signal appearances in the hypothalamus, the left lentiform nucleus and optic chasm and optic tracts, but residual changes in the form of subtle high signal persisted. Notably, the usual MRI features of HSE never developed. Four weeks after discontinuing antiviral medication, the patient developed unilateral acute retinal necrosis (ARN). The strong association of ARN with herpesviruses ${ }^{3}$ prompted further treatment with antiviral and immunosuppressive therapies. HSV-1 infection was subsequently again proven through positive vitreous PCR. Despite treatment, the present case resulted in cognitive impairment and the patient was subsequently transferred to a neurorehabilitation unit.

MRI is the modality of choice in imaging assessment of the hypothalamus. ${ }^{4}$ Lesions affecting this region can be broadly classified into the following: neoplastic (primary and secondary), developmental, inflammatory/granulomatous diseases and lesions arising from the adjacent brain parenchyma. ${ }^{4}$ Wernicke encephalopathy is an acute neurological condition resulting from a dietary Vitamin B1 (thiamine) deficiency and characteristically symmetrically involves the mamillary bodies, dorsomedial thalami, tectal plate, periaqueductal area and the grey matter around the third and fourth ventricle. ${ }^{5}{ }^{6}$ It usually happens in a background of alcoholism or GI resection.

We have presented an unusual case of proven HSE, where the typical MRI findings were absent. There was hypothalamic involvement with hypothermia, which, to the best of our knowledge, has not been described before along with putamen involvement which is also rare. HSE should be included as a differential diagnosis when evaluating acute hypothalamic lesions on MRI.

\section{Learning points}

- Herpes simplex encephalitis (HSE) can rarely involve hypothalamus and present as hypothermia. It should be included in the differential of hypothalamic lesions.

- HSE may also involve putamen, although it is rare.

- HSE can occur with absence of typical findings in temporal lobes and insula.

Competing interests None declared.

Patient consent Obtained.

Provenance and peer review Not commissioned; externally peer reviewed.

\section{REFERENCES}

1 Bulakbasi N, Kocaoglu M. Central nervous system infections of herpesvirus family. Neuroimaging Clin N Am 2008;18:53-84.

2 Adler AC, Kadimi S, Apaloo C, et al. Herpes simplex encephalitis with two false-negative cerebrospinal fluid PCR tests and review of negative PCR results in the clinical setting. Case Rep Neurol 2011;3:172-8.

3 Ganatra JB, Chandler D, Santos C, et al. Viral causes of the acute retinal necrosis syndrome. Am J Ophthalmol 2000;129:166-72.

4 Saleem SN, Said AH, Lee DH. Lesions of the hypothalamus: MR imaging diagnostic features. Radiographics 2007;27:1087-108.

5 Degnan AJ, Levy LM. Neuroimaging of rapidly progressive dementias, part 2: prion inflammatory, neoplastic, and other etiologies. AJNR Am J Neuroradiol 2014;35:424-31.

6 Zuccoli G, Gallucci M, Capellades J, et al. Wernicke encephalopathy: MR findings at clinical presentation in twenty-six alcoholic and nonalcoholic patients. AJNR Am J Neuroradiol 2007;28:1328-31.

Copyright 2016 BMJ Publishing Group. All rights reserved. For permission to reuse any of this content visit

http://group.bmj.com/group/rights-licensing/permissions.

BMJ Case Report Fellows may re-use this article for personal use and teaching without any further permission.

Become a Fellow of BMJ Case Reports today and you can:

- Submit as many cases as you like

- Enjoy fast sympathetic peer review and rapid publication of accepted articles

- Access all the published articles

Re-use any of the published material for personal use and teaching without further permission

For information on Institutional Fellowships contact consortiasales@bmjgroup.com

Visit casereports.bmj.com for more articles like this and to become a Fellow 